\title{
HUBUNGAN E-COMMERCE DAN LITERASI KEUANGAN TERHADAP KELANGSUNGAN USAHA DI BOYOLALI
}

\author{
RELATIONSHIP OF E-COMMERCE AND FINANCIAL LITERATERACY ON BUSINESS \\ CONTINUITY IN BOYOLALI
}

\author{
Samuel Wahyu Hari Christoper ${ }^{1)}$, dan Ika Kristianti ${ }^{2)}$ \\ Universitas Kristen Satya Wacana, Jl. Diponegoro 52-60 Salatiga 50711
}

\begin{abstract}
The purpose of this study is to find out whether there is a relationship between e-commerce and business continuity and whether there is a relationship between financial literacy and business continuity. The method of this research is quantitative. Purposive sampling is applied in this research. The analysis technique used in this study is correlation in testing research hypotheses. Based on test results in this study that the first hypothesis is accepted, e-commerce have a relationship to business continuity. Based on the test results on the research also known that the second hypothesis is accepted, financial literacy has a relationship to business continuity. The existence of this research proves that the existence of e-commerce and financial literacy affects business continuity. Based on the development of information technology, an entrepreneur must be able to implement e - commerce and understand the importance of financial literacy in running his business.
\end{abstract}

Key words: e-commerce, financial literacy, business continuity

\begin{abstract}
ABSTRAK
Tujuan dari penelitian ini adalah untuk mengetahui apakah ada hubungan antara e-commerce terhadap kelangsungan usaha dan apakah ada hubungan Antara literasi keuangan terhadap kelangsungan usaha. Penelitian ini adalah penelitian kuantitatif dengan metode pemilihan sampel yaitu dengan metode purposive sampling.Teknik analisis yang digunakan dalam penelitian ini adalahkorelasi dalam pengujian hipotesis penelitian. Berdasarkan hasil pengujian pada penelitian ini bahwa hipotesis pertama diterima,e-commerce memiliki hubungan terhadap kelangsungan usaha. Berdasarkan hasil pengujian pada penelitian juga diketahui hipotesis kedua diterima, literasi keuangan memiliki hubungan terhadap kelangsungan usaha. Dengan adanya penelitian tersebut membuktikan bahwa dengan adanya e-commerce dan literasi keuangan berpengaruh terhadap kelangsungan usaha. Yang ditunjukan oleh perkembangan teknologi informasi membuat searang wirausahawan harus mampu menerapkan e-commerce dan memahami arti penting literasi keuangan dalam menjalankan usahanya.
\end{abstract}

Kata kunci: e-commerce, literasi keuangan, kelangsungan usaha

Corresponding author : Samuel Wahyu Hari Christoper*

Email for author : 232015157@student.uksw.edu*, ika.kristianti@uksw.edu

Submission : 14 November 2019

Revised :02 Februari 2020

Accepted : 03 Februari 2020

DOI $\quad:$ https://doi.org/10.33369/j.akuntansi.9.3.1-12 


\section{PENDAHULUAN}

Masyarakat saat ini belum mampu untuk memasarkan produk yang dimiliki, meskipun telah memproduksi barang maupun jasa secara maksimal (Wahyuningrum dan Januarita 2014). Banyaknya potensi produk maupun jasa pada masyarakat belum secara baik terserap oleh daya beli masyarakat. Dalam salah satu potensi tersebut, salah satunya adalah potensi dari usaha kecil dan menengah. Dengan adanya kemudahan saat ini, pelaku usaha dapat memasarkan produk dibantu oleh platform media sosial sebagai salah satu contohnya. Penggunaan e-commerce dapat membantu pelaku usaha untuk memasarkan produk secara online dan menerima pesanan. Sifat masyarakat yang konsumtif semakin dimudahkan dengan adanya $e$-commerce seperti yang diungkapkan (Lacka dan Yip, 2018). Kebutuhan masyarakat semakin tinggi dan waktu yang dimiliki oleh masyarakat semakin berkurang, e-commerce dapat memberikan kemudahan dalam menawarkan barang kepada masyarakat yang intensitas hidupnya semakin padat. Peluang usaha ini dimanfaatkan oleh masyarakat atau pelaku usaha untuk merintis usahanya tanpa harus membuka tempat usaha (offline store). Seperti kebanyakan pelaku usaha lain yang memanfaatkan selebgram untuk memasarkan barang-barang melalui instagram ataupun media sosial lain seperti facebook ataupun bukalapak, tokopedia, shopee, dan masih banyak lagi.

Berkembangnya teknologi semakin maju pada saat ini, perusahaan yang termasuk dalam kategori industri kecil, menengah, ataupun besar sekalipun mereka tetap harus bersaing dengan baik di masa berkembangnya teknologi. Liu, College, Company, Koh, dan Kappelman (2001) mengatakan bahwa internet memberikan peran dan manfaat yang penting bagi para pelaku usaha untuk memasuki pasar secara mudah, yang dulunya pasar tradisional dimana harus bertemunya penjual dan pembeli serta membutuhkan waktu untuk sampai kelokasi, namun dengan adanya web dan internet saat ini, proses pelaksanaan transaksi tidak harus terjadi pertemuan diantara pembeli dan penjual, serta dapat diakses secara mudah, murah, dan tanpa batasan geografis.

Perkembangan e-commerce yang terjadi membuat masyarakat harus memahami tentang pencatatan dan literasi keuangan yaitu tentang pengetahuan, keyakinan, keterampilan masyarakat terkait lembaga keuangan serta produk dan jasanya. Otoritas Jasa Keuangan (2017) menyatakan bahwa dengan adanya pengetahuan tentang tentang literasi keuangan bisa memberikan pemahaman tentang pengelolaan keuangan untuk mencapai kehidupan yang lebih baik dimasa yang akan datang, literasi keuangan juga berperan penting dalam kehidupan untuk pengambilan keputusan seperti menabung ataupun berinvestasi untuk mencapai tujuan yang sudah ditentukan sebelumnya. Melalui pengelolaan keuangan yang baik, masyarakat akan dapat mengelola keuangan dengan baik sehingga kesejahteraan ekonomi dapat tercapai. Survei yang dilakukan OJK di Indonesia literasi keuangan mulai meningkat yang semulanya $21,8 \%$ pada tahun 2013 dan menjadi 29,7\% ditahun 2016 masyarakat Indonesia yang melek keuangan. Hal ini menunjukan bahwa pengetahuan keuangan masyarakat Indonesia masih rendah.

IPTEK yang semakin berkembang pada era saat ini membuat masyarakat sebagai pelaku usaha juga mulai memanfaatkan e-commerce dalam kegiatan bisnis mereka. Hal tersebut dibuktikan dengan kemunculan berbagai aplikasi penjualan online di Indonesia, seperti bukalapak, tokopedia, shopee, dan masih banyak lagi. Martinsons (2006) menyatakan tingkat kebutuhan dan kemajuan iptek saat ini membuat pendapatan masyarakat juga mengalami perkembangan. Banyak pengusaha di seluruh dunia yang memanfaatkan internet untuk memulai peluang usahanya melalui media sosial. Namun peningkatan pendapatan yang tidak disertai pemahaman pengelolaan keuangan dapat meningkatkan kesejahteraan masyarakat?

Chen et al. (2018) mengatakan bahwa kelangsungan usaha (going concern) bukan hanya tergantung dengan pendapatan yang diterimanya melainkan mengacu pada pendapat perhatian audit yang saat ini terjadi bahwa perusahaan yang diganjar, akan pendapat perhatian yang 
menguntungkan asalkan memenuhi kewajiban utang ditahun berikutnya untuk kelangsungan usaha kedepannya.

Berdasarkan uraian latar belakang diatas, dapat diidentifikasikan beberapa faktor-faktor yang mendasari masalah penelitian ini adalah e-commerce merupakan model bisnis yang sedang menjamur dan populer dikalangan masyarakat dikarenakan tuntutan tingkat pendapatan masyarakat yang tinggi dan masyarakat yang semakin konsumtif sehingga tingkat kebutuhan juga semakin tinggi, namun sangat disayangkan tingkat pengetahuan literasi keuangan di Indonesia yang masih terbilang sangat rendah yang berpengaruh terhadap kelangsungan usahanya

Berdasarkan identifikasi masalah yang diuraikan di atas, tampak jelas bahwa permasalahan yang terkait dengan topik penelitian sangat luas. Banyaknya permasalahan yang ada dan faktor-faktor yang mempengaruhi berkaitan dengan e-commerce, literasi keuangan dan tingkat pendapatan masyarakat, penelitian dibatasi pada lokasi Boyolali.Pemilihan lokasi penelitian ini berdasarkan adanya peningkatan UMKM Boyolali yang terhitung dari tahun 2014 hingga tahun 2018. Berdasarkan dari 4 tahun terakhir tersebut, UMKM Boyolali telah mengalami peningkatan sejumlah 493 unit usaha baru. Data tersebut diperoleh dari hasil wawancara yang dilakukan dengan Kepala DISKOPNAKER Boyolali. Selain itu, seiring dengan tuntutan zaman, peneliti juga ingin memiliki kontribusi dalam pengembangan wilayah tempat tinggal. Berdasarkan fenomena yang terjadi, maka penelitian ini bertujuan untuk menganalisis adakah hubungan antara e-commerce serta literasi keuangan terhadap kelangsungan usaha terutama di Kabupaten Boyolali.

\section{KERANGKA TEORITIS DAN HIPOTESIS}

\section{E-commerce}

Menurut Karmawan et al. (2010) e-commerce adalah bisnis yang dilakukan secara elektronik yang difokuskan kepada transaksi yang memanfaatkan internet (teknologi berbasis jaringan digital) merupakan alat pertukaran barang atau jasa baik antara dua institusi ataupun institusi dengan konsumen tanpa melihat kendala yang dominan selama ini yaitu adanya jarak ruang dan waktu. Dengan adanya e-commerce merupakan relasi antara perusahaan dengan entitas eksternal lainya seperti distributor, produsen, konsumen dapat dilakukan dengan cepat, mudah, dan dapat meminimalisir biaya dibandingkan prinsip manajemen secara konversal.

Wahyuningrum dan Januarita (2014) mengatakan bahwa electronic commerce atau sering disebut dengan e-commerce merupakan perdagangan yang dilakukan secara elektronik, Undang-Undang Nomor 11 Tahun 2008 mengatur e-commerce yaitu tentang internet dan transaksi elektronik, didalam e-commerce bukan hanya tentang pembelian dan penjualan barang dan jasa tetapi e-commerce juga ada pelayanan pelanggan, kolaborasi dengan mitra bisnis dan dan transaksi dalam perusahaan. Dengan adanya e-commerce semua kegiatan mungkin bagi sebagian orang merasa kesulitan dikarenakan terhalang oleh jarak dan waktu, kini semua kegiatan itu mudah dilakukan dimana saja dan kapan saja bahkan lebih efektif dan efisien.

\section{Literasi Keuangan}

Latifiana (2016) mengemukakan kemampuan dalam merencanakan harus dimiliki oleh pelaku bisnis untuk melaksanakan dan mengawasi bisnis dan pengelolaan keuangannya, bukan hanya mampu melakukan perencanaan saja untuk mendapatkan hasil yang maksimal, pelaku usaha juga harus mampu untuk mengambil keputusan secara efisien dan efektif. Untuk mengambil keputusan secara efektif dan efisien pelaku bisnis harus mempunyai pengetahuan pengelolaan keuangan yang baik, kemampuan inilah yang dikenal sebagai literasi keuangan. Menurut Otoritas Jasa Keuangan (2017) perencanaan keuangan tentang bagaimana cara untuk menjalani hidup pada hari ini yang sederhana dan sesuai dengan kemampuan keuangan serta 
menyiapkan masa depan yang baik dan sejahtera.

Triwijayani (2006) mengungkapkan jenis kelamin tidak menunjukan adanya perbedaan terhadap kemampuan mengelola keuangan melainkan lama usaha dan pendidikan lah yang mempengaruhi tingkat literasi keuangan dikarenakan tingkat pendidikan yang rendah memiliki tingkat pengetahuan keuangan yang minim begitupun sebaliknya dengan pendidikan yang tinggi para pelaku UMKM bisa mengetahui bagaimana cara mengelola pencatatan transaksi dan mengambil keputusan dengan bijak. Lama dalam usaha juga memiliki tingkat pengetahuan tentang pengelolaan keuangan dengan baik dikarenakan telah lama dia berusaha.

\section{Kelangsungan Usaha}

Kawasan, Mulur, dan Kasus (2015) mengatakan ada 4 aspek penting yang perlu diperhatikan dalam usaha yaitu permodalan, sumber daya manusia, produksi, dan pemasaran, dengan memahami aspek-aspek tersebut para pelaku usaha dapat mempertahankan usahnya. Modal merupakan hal yang paling penting untuk keberlangsungan usaha, modal dapat diperoleh dari diri sendiri maupun pinjaman. Selain modal, sumber daya manusia dan keahlian juga diperlukan supaya usaha yang sudah dimulai dapat berlangsung dengan baik, sehingga dapat mencapai tujuan yang diinginkan. Kegiatan produksi digunakan untuk menghasilkan nilai kegunaan baru dari barang atau jasa yang diperlukan bagi pemenuhan kebutuhan konsumen. Pemasaran juga memiliki peran penting dalam keberlangsungan usaha, dan memiliki teknik pemasaran yang baik dan tepat, usaha dapat berkembang dengan pesat.

\section{Hubungan E-commerce Terhadap Kelangsungan Usaha}

E-commerce mempunyai hubungan yang erat dengan kelangsungan usaha, e-commerce merupakan penjualan secara elektronik yang memudahkan penjual dan pembeli untuk melakukan transaksi, dengan adanya e-commerce perkembangan dunia usaha saat ini sangatlah pesat, salah satunya pada penelitian ini Chan dan Al-Hawamdeh, (2002) terlihat bahwa banyak pelaku bisnis di Singapura memanfaatkan pengembangan e-commerce yang ada untuk memulai bisnis online mereka. hal tersebut didukung karena adanya kemajuan dalam teknologi dan informasi. Segala bentuk kegiatan usaha di era modern tidak lepas dari penggunaan teknologi informasi tersebut. E-commerce merupakan contoh nyata dari kegiatan ekonomi modern, menurut dari penelitian Kumar dan Petersen, (2006) e-commerce mengurangi kesalahan pemrosesan, mengurangi waktu respon, mengurangi biaya layanan, dan telah secara efektif meningkatkan kepuasan pelanggan dan tingkat layanan. Perkembangan kegiatan ekonomi ini tidak hanya dialami oleh penjual saja, melainkan dialami oleh pelaku ekonomi yang lain seperti konsumen atau distributor. Eva (2017) mengungkapkan bahwa e-commerce memberikan alternatif sebagai media pemasaran produk bagi usaha kecil, meskipun penggunaan teknologi yang masih rendah namun persepsi pelaku bisnis UMKM terhadap maanfaat teknologi internet tersebut memberikan implementasinya pada masa manfaat yang akan datang. Sehingga hipotesis yang dapat diambil adalah semakin orang memahami e-commerce maka keberlangsungan usaha yang dimiliki akan meningkat berdasarkan uraian hipotesis di atas hipotesis yang dapat disusun yaitu:

H1: Terdapat hubungan antara e-commerce dengan kelangsungan usaha.

\section{Hubungan literasi keuangan terhadap kelangsungan usaha}

Literasi keuangan mempunyai hubungan yang erat terhadap kelangsungan usaha, Dalam menjalankan usaha bukan hanya tentang pencatatan transaksi maupun pencatatatn keuangan, dalam menjalankan usaha juga memerlukan pengawasan dan perencanaan terhadap usahanya maupun terhadap pengelolaan keuangan, dalam menjalankan usahanya bukan hanya dibutuhkan perencanaan dan pengawasan saja tetapi juga bisa dalam pengambilankeputusan 
yang efektif dan efisien disaat keadaan perusahaan yang sedang naik turun agar hasil yang di dapat secara maksimal. Latifiana (2016) setiap pengusaha harus menciptakan manajemen yang baik dalam pengambilan keputusan seperti pemasaran, keuangan dan berinvestasi untuk menghadapi persaingan agar usahanya tetap terus berjalan. Rahayu dan Apristi, (2017) menyatakan bahwa literasi keuangan mempengaruhi kinerja dan keberlangsungan usaha, semakin tinggi tingkat literasi keuangan, pemilik bisnis dapat mengelola bisnis mereka dengan baik. Seperti yang diungkapkan oleh Aribawa, (2016) dengan literasi keuangan yang baik diharapkan pelaku usaha dapat mengambil keputusan manajemen dan keuang anyang tepat untuk peningkatan kinerja dan keberlangsungan usaha. Sehingga hipotesis yang dapat di ambil adalah semakin orang memahami literasi keuangan maka keberlangsungan usaha yang dimiliki juga akan meningkat hipotesis tersebut didukung oleh penelitian berdasarkan uraian hipotesis diatas hipotesis yang dapat disusun yaitu:

H2: Terdapat hubungan antara literasi keuangan dengan kelangsungan usaha.

\section{Hubungan E-commerce dan Literasi Keuangan Terhadap Kelangsungan Usaha}

Kesuksesan usaha diekonomi modern tidak lepas dari peranan perkembangan teknologi informasi. Seorang wirausahawan harus memiliki pengetahuan dan skil dalam menjalankan ushanya sesuai dengan kebutuhan zaman tingginya mobilitas teknologi informasi saat ini menuntut kegiatan usaha tidak terbatas pada bertemunya penjual dan pembeli secara langsung (pasar tradisional). Kegiatan ekonomi dapat dilakukan dimana saja dan kapan saja, sehingga seorang wirausahawan harus mengetahui bentuk kegiatan wirausahawan di era digital $e$ commerce Rejeki, Utomo, dan Susanti, (2011) juga mengemukakan bahwa dengan adanya penjualan secara elektrik segala kegiatan jual beli semakin mudah serta memperluas pemasaran dan meningkatkan loyalitas pembeli, bukan hanya dengan perluasan pemasaran dalam melakukan usaha melainkan dengan menambahkan inovasi, meningkatkan akses permodalan dan diverifikasi produk Budi dan Dedy, (2013). Kegiatan wirausaha bukan hanya tentang penjualan saja melainkan juga meliputi pengelolaan keuangan, seperti yang diungkapkan oleh Oseifuah, (2010) dengan mengetahui keterampilan dalam mengelola keuangan bisa berimplikasi terhadap keberlangsungan usaha. jika seorang wirausahawan memiliki keterampilan penjualan yang baik namun tidak memiliki keterampilan dalam mengelola keuangan kegiatan usaha juga tidak akan berjalan lancar berdasarkan hal tersebut dapat dikatakan bahwa pengetahuan akan pengelolaan keuangan sangatlah dibutuhkan baik itu perencanaan keuangan, tabungan, investasi, maupun asuransi.Sehingga dapat ditarik hipotesis bahwa e-commerce dan literasi keuangan berpengaruh terhadap kelangsungan usaha.

H3: Terdapat hubungan antara e-commerce dan literasi keuangan dengan kelangsungan usaha.

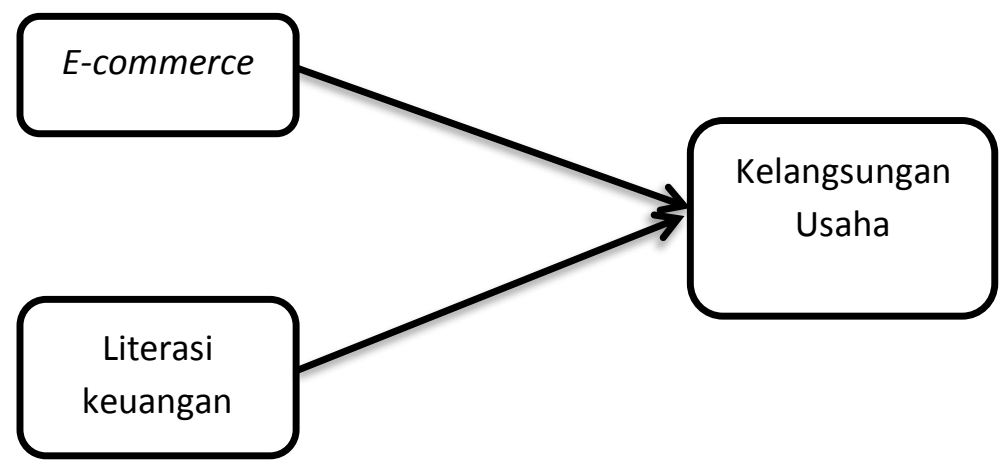

Gambar 1. Model Penelitian 


\section{METODE PENELITIAN}

\section{Jenis dan Sumber Data}

Jenis penelitian ini ialah penelitian kuantitatif dengan menggunakan data primer. Data primer yang digunakan pada penelitian ini dalam bentuk jawaban atau persepsi responden penelitian melalui penyebaran kuesioner pada sampel yang yang dibagikan secara acak. Sumber data yang digunakan dalam penelitian ini berupa hasil kuesioner yang diisi responden, terdiri dari hasil jawaban responden yang telah dikumpulkan.

\section{Populasi dan Sampel}

Populasi dalam penelitian ini adalah seluruh UKM yang ada di Kabupaten Boyolali. Pada penelitian ini data yang digunakan adalah sebanyak 100 sampel wirausahawan dengan menggunakan rumus slovin dengan tingkat kegagalan sebesar $5 \%$. Teknik pengambilan sampel digunakan untuk menentukan sampel pada penelitian, pengambilan sampel pada penelitian ini penulis menggunakan Teknik Purposive sampling. Menurut Sugiyono (2012) pengertian Purposive sampling adalah menentukan sampel dengan pertimbangan tertentu. Menggunakan teknik ini karena tidak seluruh sampel mempunyai kriteria yang sesuai dengan yang sudah ditentukan, yang perlu dipenuhi oleh sampel pada penelitian ini yaitu :

1. Sampel harus memahami e-commerce (berbagai transaksi penjualan dilakukan secara daring /dalam jaringan)

2. Sampel harus memahami literasi keuangan (perbankkan, asuransi, lembaga pembiyayaan, pasar modal, keterampilan keuangan)

3. Sampel harus memiliki usaha kurang lebih 3 tahun

4. Sampel memiliki tempat usaha

\section{Definisi Operasional dan Pengukuran Variabel}

Sugiyono (2015) Mengungkapkan bahwa variabel penelitian adalah segala sesuatu yang berbentuk apa saja yang ditetapkan oleh peneliti untuk dipelajari dan diperoleh informasi mengenai hal tersebut, kemudian ditarik kesimpulan.Pada penelitian ini, peneliti menggunakan tiga variabel yaitu variabel e-commerce, variabel literasi keuangan, variabel kelangsungan usaha.

Tabel 1. Definisi Operasional

\begin{tabular}{|c|c|c|c|}
\hline No & Variabel & Difinisi Oprasional & Indikator \\
\hline 1. & E-commerce & $\begin{array}{l}\text { E-commerce merupakan perdagangan yang } \\
\text { dilakukan secara elektronik, E-commerce tidak } \\
\text { hanya pembelian dan penjualan barang serta jasa } \\
\text { tetapi juga pelayanan pelanggan (Jauhari, 2010) }\end{array}$ & $\begin{array}{l}\text { 1. Perdagangan mobile } \\
\text { 2. Pemasaran } \\
\text { 3. Pembayaran }\end{array}$ \\
\hline 2. & $\begin{array}{l}\text { Literasi } \\
\text { Keuangan }\end{array}$ & $\begin{array}{l}\text { Literasi Keuangan merupakan pelaku bisnis harus } \\
\text { memiliki harus memiliki kemampuan dalam } \\
\text { merencanakan, melaksanakan, mengawasi } \\
\text { pelaksanaan pengelolaan keuangan (Latifiana, } \\
\text { 2016) }\end{array}$ & $\begin{array}{ll}\text { 1. } & \text { Perbankan } \\
\text { 2. Asuransi } \\
\text { 3. Lembaga } \\
\text { pembiyayaan } \\
\text { 4. Keterampilan } \\
\text { keuangan } \\
\end{array}$ \\
\hline 3. & $\begin{array}{l}\text { Kelangsungan } \\
\text { Usaha }\end{array}$ & $\begin{array}{l}\text { keadaan suatu kondisi usaha, didalamnya } \\
\text { terdapat cara-cara untuk mempertahankan, } \\
\text { mengembangkan dan memenuhi kebutuhan } \\
\text { didalam suatu usaha (Kawasan et al. 2015) }\end{array}$ & $\begin{array}{l}\text { 1. Peningkatan modal } \\
\text { 2. Jumlah produksi } \\
\text { 3. Perluasan usaha } \\
\text { 4. Pendapatan usaha }\end{array}$ \\
\hline
\end{tabular}




\section{Skala Pengukuran}

Melalui penyebaran kuesioner untuk pengumpulan data primer akan dibentuk dalam skala pengukuran. Skala pengukuran merupakan acuan untuk menentukan panjang pendeknya interval, bila digunakan dalam pengukuran akan menghasilkan data kuantitatif (Sugiyono, 2012). Skala likert yang digunakan dalam penelitian ini untuk menganalisis data kuantitatif, dan jawaban yang diberikan responden memiliki skor sebagai berikut:

Tabel 2. Skala Pengukuran

\begin{tabular}{ccc}
\hline No. & Sikap Responden & Skor \\
\hline 1. & Sangat tidak setuju & 1 \\
\hline 2. & Tidak setuju & 2 \\
\hline 3. & Ragu-ragu & 3 \\
\hline 4. & Setuju & 4 \\
\hline 5. & Sangat setuju & 5 \\
\hline
\end{tabular}

Jawaban dari responden yang diperoleh akan menghasilkan data ordinal. Data primer yang merupakan skala likert akan dianalisis berdasarkan metode analisis data yang digunakan.

\section{Teknik Pengumpulan Data}

Teknik pengumpulan data dilakukan dengan cara interview (wawancara), kuesioner (angket). Kuesioner merupakan teknik pengumpulan data yang dilakukan dengan cara memberi pertanyaan atau pernyataan tertulis kepada responden untuk dijawab (Sugiyono, 2007). Kuesioner pada penelitian ini berupa pernyataan yang diberikan kepada responden untuk dipilih atau dijawab.

\section{Teknik Analisis Data}

Teknik analisis data yang digunakan dalam penelitian adalah teknik analisis korelasi dan analisis regresi ganda multiple regression. Analisis regresi ganda adalah teknik analisis tentang hubungan satu variabel terkait dependent variable dengan dua atau lebih variabel bebas independent variabel.

\section{HASIL DAN PEMBAHASAN}

\section{Tempat dan Waktu Penelitian}

Penelitian ini dilaksanakan pada pelaku usaha yang berada di Boyolali. Pengumpulan data melalui kuesioner penelitian yang diberikan secara langsung kepada responden. Penyebaran dan pengumpulan kuesioner dilaksanakan tanggal 12 Agustus 2019 sampai dengan 6 September 2019 dengan jumlah sebesar 110 responden pelaku usaha.

\section{Karakteristik Responden Penelitian}

Adapun karakteristik responden dari penelitian ini adalah sebagai berikut :

Tabel 3. Karakteristik Responden

\begin{tabular}{ccc}
\hline Kategori & Keterangan & Jumlah \\
\hline Jenis Kelamin & Pria & 57 \\
\cline { 2 - 3 } & Wanita & 53 \\
\hline
\end{tabular}


Samuel Wahyu Hari Christoper dan Ika Kristianti

\begin{tabular}{lcc}
\hline Kategori & Keterangan & Jumlah \\
\hline Usia & $<30$ Tahun & 44 \\
\cline { 2 - 3 } & 30-40 Tahun & 45 \\
\cline { 2 - 3 } & $>40$ Tahun & 21 \\
\hline
\end{tabular}

Berdasarkan karakteristik jenis kelamin responden pada tabel 3 diatas diketahui bahwa responden pria sebanyak 57 orang sedangkan responden wanita sebanyak 53 orang. Sedangkan dilihat dari segi usia yang paling banyak dalam usia 30-40 tahun dengan jumlah responden 45 orang sedangkan yang kurang dari 30 tahun sebanyak 44 orang, ada juga yang lebih dari 40 tahun sebanyak 21 responden.

\section{Uji Instrumen dan Uji Asumsi Klasik}

Dalam penelitian ini untuk mengukur validitas instrumen penelitian dengan melihat pearson corelation, dari hasil uji validitas diperoleh hasil variabel penelitian ini dari semua hasil nilai signifikansinya $<0,05$. Dari hasil uji tersebut menunjukan seluruh pernyataan dalam kuesioner dapat dinyatakan valid. Dengan demikian seluruh butir pernyataan dalam kuesioner penelitian dapat digunakan dalam penelitian ini. Salah satu metode pengujian reliabilitas adalah dengan menggunakan cronbach's alpha. Dari uji reliabilitas variabel e-commerce menunjukan nilai 0,840 , variabel literasi keuangan menunjukan nilai 0,675 , dan variabel kelangsungan usaha menunjukan nilai 0,796 . Nilai-nilai tersebut menunjukan instrumen penelitian masuk dalam kategori reliabel karena lebih besar dari 0,60.

Penelitian ini juga menggunakan uji asumsi klasik seperti uji normalitas, uji heterokedastisitas, dan uji multikoloniearitas. Dari hasil uji yang sudah dilakukan menunjukan bahwa dalam penelitian terhindar dari heterokedastisitas dan multikoloniearitas sehingga berdistribusi normal.

Tabel 4. Korelasi X1 dengan Y

\begin{tabular}{llll}
\hline \multirow{2}{*}{ E-commerce } & \multicolumn{1}{c}{ E-commerce } & Kelangsungan Usaha \\
& $\begin{array}{l}\text { Pearson } \\
\text { Correlation }\end{array}$ & 1 & $.507^{* *}$ \\
\cline { 2 - 4 } & Sig. (2-tailed) & & 0 \\
\cline { 2 - 4 } & $\mathrm{N}$ & 100 & 100 \\
\hline $\begin{array}{l}\text { Kelangsungan } \\
\text { usaha }\end{array}$ & $\begin{array}{l}\text { Pearson } \\
\text { Correlation }\end{array}$ & $.507^{* *}$ & 1 \\
\cline { 2 - 4 } & Sig. (2-tailed) & 0 & \\
\cline { 2 - 4 } & $\mathrm{N}$ & 100 & 100 \\
\hline
\end{tabular}

Berdasarkan tabel uji korelasi dapat diketahui $\mathrm{r}_{\text {hitung }}$ menggunakan pearson correlation hubungan antara e-commerce dengan kelangsungan usaha sebesar 0,507 sehingga terdapat korelasi sedang, dengan nilai signifikansi 0,000. Jika dibandingkan dengan $r_{\text {tabel }}$ dengan signifikansi sebesar 0,05 diperoleh $r_{\text {tabel }} 0,1638$ maka nilai $r_{\text {hitung }}>r_{\text {tabel }}(0,507>0,1638)$ maka terdapat hubungan yang signifikan antara e-commerce dengan kelangsungan usaha. 
Tabel 5. Korelasi X2 dengan Y

\begin{tabular}{llcc}
\hline \multicolumn{1}{c}{ Keterangan } & $\begin{array}{c}\text { Literasi } \\
\text { Keuangan }\end{array}$ & $\begin{array}{c}\text { Kelangsungan } \\
\text { Usaha }\end{array}$ \\
\hline Literasi & $\begin{array}{l}\text { Pearson } \\
\text { Keuangan }\end{array}$ & 1 & $.585^{* *}$ \\
\cline { 2 - 4 } & $\begin{array}{l}\text { Correlation } \\
\text { Sig. (2-tailed) }\end{array}$ & 100 & 0 \\
\cline { 2 - 4 } $\begin{array}{l}\text { Kelangsungan } \\
\text { Usaha }\end{array}$ & $\begin{array}{l}\text { Pearson } \\
\text { Correlation }\end{array}$ & $.585^{* *}$ & 100 \\
\cline { 2 - 4 } & Sig. (2-tailed) & 0 & 1 \\
\cline { 2 - 4 } & $\mathrm{N}$ & 100 & 100 \\
\hline
\end{tabular}

Berdasarkan tabel uji korelasi dapat diketahui $\mathrm{r}_{\text {hitung }}$ menggunakan pearson correlation hubungan antara literasi keuangan dengan kelangsungan usaha sebesar 0,585 sehingga terdapat korelasi sedang, dengan nilai signifikansi 0,000. Jika dibandingkan dengan $r_{\text {tabel }}$ dengan signifikansi sebesar 0,05 diperoleh $r_{\text {tabel }} 0,1638$ maka nilai $r_{\text {hitung }}>r_{\text {tabel }}(0,585>0,1638)$ maka terdapat hubungan yang signifikan antara literasi keuangan dengan kelangsungan usaha.

Tabel 6. Korelasi Multiple X1, X2 dengan Y

\begin{tabular}{ccccc}
\hline Model & $\mathrm{R}$ & $\mathrm{R}$ Square & Adjusted R Square & Std. Error of the Estimate \\
\hline 1 & $.646 \mathrm{a}$ & 0.417 & 0.405 & 2.427 \\
\hline
\end{tabular}

Dari hasil uji diatas diperoleh nilai koefisien korelasi ganda $\mathrm{R}$ sebesar 0,646 yang menunjukan bahwa terdapat hubungan antara variabel $\mathrm{Y}$ dan variabel-variabel bebas adalah kuat karena lebih dari 0,05 .

\section{Pembahasan}

Hasil penelitian menunjukan bahwa e-commerce berhubungan terhadap kelangsungan usaha. Hal ini terbukti dari perdagangan menggunakan media internet (commerce-mcommerce), bisnis ke konsumen (bussines-to-consumer-B2C), konsumen ke bisnis (consumerto-bussines) yang setelah dilakukan oleh wirausaha memiliki peranan yang sangat penting terhadap kelangsungan usaha, dengan adanya e-commerce mempermudah pelaku usaha dalam melakukan transaksi, dapat dibuktikan banyaknya pelaku usaha yang menggunakan media sosial dalam memasarkan produknya. Hasil penelitian ini sejalan dengan yang dikemukakan oleh Polatogu (2007) dalam penelitiannya memberikan informasi tentang e-commerce yang telah dirancang untuk meningkatkan kinerja pengecer buku kecil menjadi toko buku online terbesar di Turki, begitu pula dengan Ngoasong (2017) mengungkapkan cara-cara e-commerce membentuk pilihan entri (atau start-up) dan keputusan strategis pasca-entri pengusaha digital dalam menanggapi peluang dan tantangan spesifik konteks yang terkait dengan kewirausahaan digital. Yrle et al (2006) mengungkapkan penggunaan konsep e-commerce / aplikasi layanan internet untuk memungkinkan perusahaan wirausaha untuk bersaing secara efektif di pasar global. Berdasarkan hasil penelitian kemunculan e-commerce diera digital saat ini berhubungan terhadap proses kelangsungan usaha bagi wirausahawan. Segala bentuk kemudahan layanan yang dimiliki e-commerce dapat memiliki peran bagi setiap wirausahawan dalam menjalankan bisnisnya.

Hasil penelitian ini juga menunjukan bahwa literasi keuangan memiliki hubungan positif terhadap kelangsungan usaha. Melalui hasil penelitian tersebut pengetahuan tentang 
produk produk keuangan yang meliputi perbankan, asuransi, lembaga pembiyayaan, pasar modal, dan keterampilan keuangan diperlukan untuk menunjang untuk kelangsungan usaha. Hasil penelitian ini sejalan dengan konsep peneliti terdahulu Abubakar (2015) Hasil penelitian menunjukkan bahwa kesulitan dalam akses ke keuangan, akses ke pasar, dukungan kebijakan dan budaya kewirausahaan adalah masalah utama dan kendala pada pengembangan kewirausahaan di Afrika, begitu juga dengan Li dan Qian (2019) Hasil empiris menunjukkan bahwa literasi keuangan memiliki efek positif signifikan terhadap partisipasi wirausaha, serta pada kinerja wirausaha. Serta Oseifuah (2010) mengungkapkan bahwa melek finansial di kalangan wirausaha muda di Distrik Vhembe tampaknya di atas rata-rata dan memberikan kontribusi yang berarti bagi keterampilan kewirausahaan mereka. Berdasarkan penelitian yang dilakukan pemahaman atau pengetahuan tentang keuangan berhubungan bagi kelangsungan usaha. Produk-produk keuangan dapat mempermudah seorang wirausahawan dalam mengembangkan modal sampai dengan penjaminan dalam keamanan keuangan saat menjalankan usaha

\section{PENUTUP}

Penelitian ini bertujuan untuk memberikan bukti adanya hubungan antara $e$-commerce serta literasi keuangan terhadap kelangsungan usaha. Penelitian ini menggunakan 100 pelaku usaha (wirausahawan) yang berada di Kabupaten Boyolali sebagai sampelnya. Berdasarkan hasil penelitian diperoleh kesimpulan bahwa terdapat hubungan antara $e$-commerce terhadap kelangsungan usaha, serta ada hubungan antara literasi keuangan dengan kelangsungan usaha. Implikasi dari penelitian ini adalah perlu adanya usaha dari pelaku usaha dalam penggunaan $e$ commerce untuk memasarkan produk dan jasanya serta peningkatan pemahaman literasi keuangan untuk menunjang kegiatan bisnisnya. Pemerintah Kabupaten juga hendaknya mengadakan program peningkatan maupun workshop untuk penggunaan e-commerce serta pengenalan literasi keuangan bagi pelaku usaha untuk mempertahankan kelangsungan bisnis UKM. Keterbatasan dari penelitian ini adalah penggunaan variabel terikat yang terbatas, dalam penelitian selanjutnya dimungkinkan untuk menambah variabel lain seperti jenis usaha, aspek demografis pelaku usaha, serta kecukupan modal usaha. Selain itu, wawancara kepada responden juga bisa dilakukan untuk menguatkan analisis secara lebih mendalam. 


\section{DAFTAR PUSTAKA}

Abubakar, H. A. (2015). Entrepreneurship development and financial literacy in Africa. Management and Sustainable Development Article information.

Aribawa, D. (2016). Pengaruh literasi keuangan terhadap kinerja dan keberlangsungan UMKM di Jawa Tengah. Jurnal Siasat Bisnis.

Budi, S., \& Dedy, E. (2013). Strategi Pengembangan Usaha Kecil Menengah Dalam Mempertahankan Kelangsungan Usaha UKM (Studi pada Dinas Koperasi, UKM, Perindustrian dan Perdagangan Kota Batu ). Jurnal Administrasi Publik.

Chan, B., \& Al-Hawamdeh, S. (2002). The development of e-commerce in Singapore. Business Process Management Journal.

Eva, A. (2007). Persepsi Penggunaan Aplikasi Internet Untuk Pemasaran Produk Usaha Kecil Menengah. Seminar Nasional Aplikasi Teknologi Informasi (SNATI).

Jauhari, J. (2010). Upaya Pengembangan Usaha Kecil Dan Menengah (Ukm) Dengan Memanfaatkan E-Commerce. Jurnal Sistem Informasi (JSI).

Karmawan, I. M., Sumdjaja, A. M., \& Luhukay, D. (2010). ANALISIS DAN PERANCANGAN E-COMMERCE PD. GARUDA JAYA. Seminar Nasional Aplikasi Teknologi Informasi (SNATI).

Kumar, S., \& Petersen, P. (2006). Impact of e-commerce in lowering operational costs and raising customer satisfaction.

Lacka, E., \& Yip, N. K. (2018). "Revealing the effect of acculturation process on e-commerce acceptance: The case of intra-European acculturation. Industrial Management \& Data Systems.

Latifiana, D. (2016). Studi Literasi Keuangan Pengelola Usaha Kecil Menengah (UKM).

Liu, S.-P., Tucker, d., Koh, C. E., \& Kappelman, L. (2001). Standard user interface in ecommerce sites. Industrial Management \& Data Systems.

Martinsons, M. G. (2006). Strategic management lessons from e-commerce. HANDBOOK OF BUSINESS STRATEGY.

sugiong, M. Z. (2017). Digital entrepreneurship in a resource-scarce context: A focus on entrepreneurial digital competencies. Journal of Small Business and Enterprise Development.

Oseifuah, E. K. (2010). Financial literacy and youth entrepreneurship in South Africa. African Journal of Economic and Management Studies.

Polatoglu, V. N. (2007). Strategies that work - the case of an e-retailer in an emerging market. International Journal of Emerging Markets.

Rahayu, Y., \& Apristi. (2017). Pengaruh Literasi Keuangan Terhadap Kinerja Dan Keberlanjutan Umkm Di Kota Surabaya. Jurnal Ilmu Manajemen. 
HUBUNGAN E-COMMERCE DAN LITERASI KEUANGAN TERHADAP KELANGSUNGAN

USAHA DI BOYOLALI

Samuel Wahyu Hari Christoper dan Ika Kristianti

Rejeki, R. S., Utomo, A. P., \& Susanti, S. S. (2011).

Perancangan dan Pengaplikasian Sistem Penjualan pada "Distro Smith" Berbasis ECommerce. Jurnal Teknologi Informasi DINAMIK Volume16.

Sugiono. (2007). Metode Penelitian Kuantitatif Kualitatif dan R\&D. Bandung: Alfabeta.

Sugiono. (2012). Metode Penelitian Kuantitatif Kualitatif dan R\&D. Bandung: Alfabeta.

Sugiono. (2015). Metode Penelitian Kombinasi (Mix Methods). Bandung: Alfabeta.

Triwijayanti, M. (2006). Analisis Tingkat Literasi Keuangan Pada Pelaku Usaha Mikro, Kecil Dan Menengah Di Kota Bandar Lampung. Jurusan Ilmu Ekonomi.

Wahyuningrum, T., \& Januarita, D. (2014). Analisis Tingkat Literasi Keuangan Pada Pelaku Usaha Mikro, Kecil Dan Menengah Di Kota Bandar Lampung.

Yrle Sandra, A. C., Hartman, S. J., \& Walsh, K. R. (2004). E-business: linking available services and entrepreneurs' needs. Journal of Small Business and Enterprise Development. 